\title{
Cardio-Electopharmacology and Vasodilating Mechanisms of Quercetin
}

\author{
Hiroyasu Satoh* and Seiichiro Nishida \\ Health Life Science, Shitennoji University, Habikino, Osaka 583-8501, Japan
}

\begin{abstract}
Quercetin, a kind of flavonoids, exerts the cardiovascular actions. In guinea pig ventricular cardiomyocytes, quercetin depresses the action potential duration (APD) and inhibited the underlying ionic currents $\mathrm{I}_{\mathrm{CaL} \cdot} \cdot \mathrm{I}_{\mathrm{Krec}} \cdot \mathrm{I}_{\mathrm{K} 1}$ in cardiomyocytes. In rat aorta, quercetin $(0.1$ to $100 \mu \mathrm{M})$ relaxed the contraction induced by pretreatment with $5 \mu \mathrm{M}$ norepinephrine (NE) in aconcentration-dependent manner. NG-monomethyl-L-arginine acetate (L-NMMA) at $100 \mu M$ reduced the quercetin $(100 \mu \mathrm{M})$-induced vasorelaxation from $97.0 \pm 3.7 \%(n=10, p<0.05)$ to $78.0 \pm 11.6 \%(n=5$, $\mathrm{p}<0.05)$. Endothelium removal as well attenuated the vasodilatation. In the presence of both $100 \mu \mathrm{M}$ L-NMMA and $10 \mu \mathrm{M}$ indomethacin, the quercetin-induced vasorelaxation was further attenuated by high $\mathrm{K}(30 \mathrm{mM})$ or 10 $\mu \mathrm{M}$ tetraethylammonium (TEA). Among $\mathrm{K}_{\mathrm{C}}$ channel inhibitors, the quercetin-induced vasodilatation was attenuated by $0.3 \mu \mathrm{M}$ apamin (sensitive to SK), but not by $30 \mathrm{nM}$ charybdotoxin (sensitive to BK and IK). Under KCl-induced vasoconstriction, the quercetin-induced vasorelaxation was attenuated by PK-C inhibitors; Gö6983 ( $\alpha-, \beta-, \gamma-, \delta$ and $\zeta$-sensitive) produced stronger than Ro-31-8425 ( $\alpha$-, $\beta$-, $\gamma$ - and $\varepsilon$-sensitive). In rat mesenteric artery, the quercetininduced vasodilatation was almost resistant to both $100 \mu \mathrm{M}$ L-NG-nitro arginine methyl ester (L-NAME) and 100 $\mu \mathrm{M}$ indomethacin. The L-NAME/indomethacin-resistant quercetin-induced vasodilatation was not modified by TEA $(1 \mathrm{mM}$ ), but was attenuated by endothelium removal and $100 \mu \mathrm{M} 18 \alpha-$ and $50 \mu \mathrm{M} 18 \beta$-glychrrhetinic acids (gap junction inhibitors). Therefore, quercetin dilates the vascular smooth muscle mediated by endothelium-dependent and -independent mechanisms.
\end{abstract}

Keywords: Quercetin; Vasodilatation; Endothelium; Gap junction; Ionic currents

\section{Introduction}

Quercetin, a flavonoid, exists as quercetin glycosides in food, beverages and herbs, and in plasma, as mainly glucuronids or sulfates of quercetin and unconjugated quercetin $[1,2]$. Quercetin can exhibit significant vasodilatation of rat arteries. In general, flavonoids are vasodilator [3] and scavenger for free radicals [4], and reduce the incidence of cardiovascular diseases and carcinogenesis [5]. Thus, quercetin exerts protective cardiovascular actions through their various pharmacological effects [6,7].

The endothelium dependency of quercetin is predominant in aorta. Most studies (including our previous reports) have shown the endotheliumdependency of the quercetin-induced vasodilatation [7,8]. However, there are several reports that quercetin is less endothelium-dependent or has only a weak endothelium dependency $[3,9]$. Quercetin can increase the intracellular $\mathrm{Ca}^{2+}$ concentration $\left[\mathrm{Ca}^{2+}\right]_{\mathrm{i}}$ in the endothelium [10]. The increase of $\left[\mathrm{Ca}^{2+}\right]_{i}$ leads to endogenous nitric oxide synthase (eNOS) activation and NO production [11], and as a result, may involve with endothelium-derived hyperpolarizing factor (EDHF) for the quercetininduced vasodilatation $[12,13]$. Plant polyphenols have been reported to induce EDHF-type relaxation [14]. The cardiovascular pharmacological actions of quercetin we have so far investigated are discussed separately in cardiac and vascular pharmacology.

\section{Cardiac Pharmacology}

The cells were prepared from tissue taken from the ventricle muscle of guinea pig hearts, using the methods similar to those described previously [15-17]. Under an anesthesia with sodium pentobarbital (30 $\mathrm{mg} / \mathrm{kg}$, i.p), the chest was opened and the aorta was cannulated in situ. The heart was dissected out and perfused with normal Tyrode solution on the Langendorff apparatus. The heart was washed out by high- $\mathrm{K}^{+}$ and low- $\mathrm{Cl}^{-}$solution (KB solution). The temperature of all solutions was maintained at $36.5^{\circ} \mathrm{C}$. Effects of quercetin on the action potentials and the ionic currents in the cardiomyocytes were investigated using an Axopatch patch-clamp amplifier (Axon Instruments, Burlingame, CA, U.S.A.) and standard techniques. The composition of the modified
Tyrode solution was (in $\mathrm{mM}$ ): $\mathrm{NaCl} 137, \mathrm{KCl} 5.4, \mathrm{CaCl}_{2} 1.8, \mathrm{MgCl}_{2}$ $1, \mathrm{NaH}_{2} \mathrm{PO}_{4} 0.3$, glucose 5 , and HEPES 5. The $\mathrm{pH}$ was adjusted to 7.4 with $\mathrm{NaOH}$. Quercetin (Tocris Biosci., Northpoint, UK) was dissolved with DMSO. The final concentration of DMSO was diluted 100 to 2000 times, and never caused any responses. The pipette solution contained (in $\mathrm{mM}$ ): $\mathrm{K}$-aspartate $110, \mathrm{KCl} 20, \mathrm{MgCl}_{2}$, EGTA $10, \mathrm{Mg}$ ATP 5, creatine phosphate 5, and HEPES 5 (pH 7.2). All values are given as mean \pm S.E.M. The differences of mean values were analyzed by Student's t-test and ANOVA for paired data, and a $p$ value of less than 0.05 was considered significant. All the experiments were carried out according to the guidelines laid down by the Nara Medical University Animal Welfare Committee, and also under the terms of the Declaration of Helsinki.

\section{Effects on the action potentials}

Under the current-clamp experiments, the isolated single cell was stimulated at $1 \mathrm{~Hz}$. The action potential amplitude (APA) and the maximum rate of depolarization (Vmax) significantly decreased by approximately $12 \%(\mathrm{n}=8)$ at $1-3 \mu \mathrm{M}$ (Table 1$)$. The resting potential (RP) was unaffected. Quercetin at $3 \mu \mathrm{M}$ prolonged the action potential duration at $75 \%\left(\mathrm{APD}_{75}\right)$ by $11.9 \pm 3.4 \%(\mathrm{n}=8, \mathrm{p}<0.05)$ and at $90 \%$ repolarizations $\left(\mathrm{APD}_{90}\right)$ by $17.9 \pm 3.0 \%(\mathrm{n}=8, \mathrm{p}<0.05)$, but not at the lower concentrations $(0.1-1 \mu \mathrm{M})$ [6]. The APD means a period for the membrane repolarization, making $\mathrm{T}$ wave on ECG. The APD is clinically reflected directly to QT interval, a period between the depolarization and the repolarization of action potential, mainly responsible for the alteration of the delayed rectifier $\mathrm{K}^{+}$current $\left(\mathrm{I}_{\text {Krec }}\right)$. Thus, the APD prolongation increases the refractory period

*Corresponding author: Dr. Hiroyasu Satoh Health Life Science Shitennoj University, 3-2-1 Gakuenmae, Habikino, Osaka 583-8501, Japan, Tel: +81-72-9563181; Fax: +81-72-956-6011; E-mail: hysat@shitennoji.ac.jp

Received April 29, 2014; Accepted June 25, 2014; Published June 27, 2014

Citation: Satoh H, Nishida S (2014) Cardio-Electopharmacology and Vasodilating Mechanisms of Quercetin. Med chem 4: 523-530. doi:10.4172/2161-0444.1000189

Copyright: ( 2014 Satoh H, et al. This is an open-access article distributed under the terms of the Creative Commons Attribution License, which permits unrestricted use, distribution, and reproduction in any medium, provided the original author and source are credited. 


\begin{tabular}{|c|c|c|c|c|c|c|}
\hline & $\mathrm{n}$ & $\begin{array}{c}\mathrm{APA} \\
(\mathrm{mV})\end{array}$ & $\begin{array}{c}\mathrm{RP} \\
(\mathrm{mV})\end{array}$ & $\begin{array}{c}\mathrm{APD}_{75} \\
(\mathrm{~ms})\end{array}$ & $\begin{array}{c}\mathrm{APD}_{90} \\
(\mathrm{~ms})\end{array}$ & $\begin{array}{c}\mathrm{V}_{\max } \\
(\mathrm{V} / \mathrm{s})\end{array}$ \\
\hline Control & 8 & $117.4 \pm 1.2$ & $-80.9 \pm 0.5$ & $77.0 \pm 2.2$ & $94.1 \pm 2.0$ & $182.8 \pm 2.5$ \\
\hline Quercetin & & & & & & \\
\hline $0.1 \mu \mathrm{M}$ & 8 & $117.6 \pm 1.2$ & $-80.6 \pm 0.6$ & $78.6 \pm 2.4$ & $95.0 \pm 2.1$ & $182.1 \pm 1.2$ \\
\hline $0.3 \mu \mathrm{M}$ & 8 & $117.8 \pm 1.1$ & $-80.7 \pm 1.0$ & $79.8 \pm 3.8$ & $97.3 \pm 2.0$ & $182.5 \pm 2.3$ \\
\hline $1 \mu \mathrm{M}$ & 8 & $114.6 \pm 1.4$ & $-80.4 \pm 2.3$ & $82.9 \pm 2.3$ & $100.3 \pm 2.6$ & $173.8 \pm 2.2$ \\
\hline $3 \mu \mathrm{M}$ & 8 & $113.7 \pm 1.2$ & $-79.7 \pm 2.1$ & $86.2 \pm 2.0$ & $110.9 \pm 2.1^{1)}$ & $161.7 \pm 2.4$ \\
\hline Washout & 8 & $110.7 \pm 1.0$ & $-80.0 \pm 0.6$ & $79.4 \pm 2.2$ & $96.8 \pm 2.4$ & $172.3 \pm 2.2$ \\
\hline
\end{tabular}

Values are represented as mean \pm S.E.M. ${ }^{1)}: \mathrm{P}<0.05,{ }^{2)}: \mathrm{P}<0.01$, with respect to control value.

Table 1: Modulation of the action potential configurations by quercetin in guinea pig ventricular cardiomyocytes.

and simultaneously elevates $\left[\mathrm{Ca}^{2+}\right]_{\mathrm{i}}[15,17]$. A washout for $15-20 \mathrm{~min}$ recovered to approximately $90 \%$ of the control value.

\section{Effects on the ionic currents}

Whole-cell patch voltage-clamp experiments were performed, and test pulses (1 sec duration) were applied to -20 to $+60 \mathrm{mV}$ and -40 to $-120 \mathrm{mV}$ from a holding potential of $-30 \mathrm{mV}$. The average capacitance was $86.1 \pm 2.0 \mathrm{pF}(\mathrm{n}=44)$ [17]. Application of quercetin $(0.1$ to $3 \mu \mathrm{M})$ inhibited the L-type $\mathrm{Ca}^{2+}$ current $\left(\mathrm{I}_{\mathrm{CaL}}\right)$ (Figure 1 ). The $\mathrm{I}_{\mathrm{CaL}}$ at $10 \mathrm{mV}$ decreased by $34.9 \pm 3.2 \%(\mathrm{n}=8, \mathrm{p}<0.05)$ at $0.3 \mu \mathrm{M}$ and by $56.8 \pm 3.3 \%(\mathrm{n}=8, \mathrm{p}<0.05)$ at $3 \mu \mathrm{M}$. The responses were produced in a concentration-dependent manner. The cells not causing run-down were chose and used for the experiments. Simultaneously, the $\mathrm{I}_{\mathrm{Krec}}$ at $60 \mathrm{mV}$ increased by $60.4 \pm 2.7 \%(\mathrm{n}=8, \mathrm{p}<0.001)$ at $0.3 \mu \mathrm{M}$ and by $89.7 \pm 3.3 \%(\mathrm{n}=8, \mathrm{p}<0.001)$ at $3 \mu \mathrm{M}$. In general, the $\mathrm{I}_{\text {Krec }}$ enhancement may protect a cell due to an APD shortening and a decline of $\left[\mathrm{Ca}^{2+}\right]_{i}$, although quercetin prolonged APD. Quercetin decreased the inwardly rectifying $\mathrm{K}^{+}$current $\left(\mathrm{I}_{\mathrm{K} 1}\right)$. Quercetin did not affect the $\mathrm{I}_{\mathrm{K} 1}$ at lower concentrations, but at $3 \mu \mathrm{M}$ inhibited it by $12.4 \pm 2.1 \%(\mathrm{n}=8, \mathrm{p}<0.05)$. The $\mathrm{I}_{\mathrm{K} 1}$ is closely related with the RP, and is not yet activated in range of -70 to $-90 \mathrm{mV}$ of $\mathrm{RP}$. The $\mathrm{I}_{\mathrm{Na}}$ (as a Vmax) decreased by approximately $18-20 \%(n=8-9)$ at higher concentrations $(1-3 \mu \mathrm{M})$ of quercetin. The effect may produce antiarrhythmic actions. These responses were almost reversible (80-90\% of control) after 20 min washout.

\section{Summary}

The experiments in guinea pig ventricular cardiomyocytes showed that (1) quercetin prolonged the APD, (2) other action potential parameters were unaffected, (3) quercetin inhibited $\mathrm{I}_{\mathrm{CaL}}, \mathrm{I}_{\mathrm{K} 1}$, and Vmax $\left(\mathrm{I}_{\mathrm{Na}}\right)$, but enhanced $\mathrm{I}_{\mathrm{Krec}}$, and (4) these responses were almost reversible after a washout. The inhibitions finally lead to decline of $[\mathrm{Ca} 2+]_{\mathrm{i}}$, resulting in the suppression of the abnormal excitations. Therefore, these electropharmacological effects of quercetin would exert many helpful and protective actions upon cardiac muscle cells under the diseased conditions.

\section{Vascular Pharmacology}

\section{Vasodilating effects on rat aorta}

Wistar male rats, weighing 150 to $250 \mathrm{~g}, 7-16$ weeks old $(\mathrm{n}=32)$, were anesthetized with ether, and euthanized by exsanguination $[18,19]$. The isolated artery was cut into $1 \mathrm{~mm}$ rings in length, suspended between two stainless steel stirrups in a bath filled with 3 $\mathrm{ml}$ modified Krebs-Henseleit solution. The modified Krebs-Henseleit solution contained $118 \mathrm{mM} \mathrm{NaCl}, 4.6 \mathrm{mM} \mathrm{KCl}, 1.2 \mathrm{mM} \mathrm{MgSO}_{4}, 1.2$ $\mathrm{mM} \mathrm{KH} \mathrm{PO}_{4}, 11.1 \mathrm{mM}$ glucose, $27.2 \mathrm{mM} \mathrm{NaHCO}_{3}, 0.03 \mathrm{mM}$ ethylene glycol-O,O'-bis (2-aminoethyl)-N,N,N',N'-tetraacetic acid (EGTA), and $1.8 \mathrm{mM} \mathrm{CaCl}_{2}$. The chamber solution was oxygenated with $95 \%$ $\mathrm{O}_{2}$ and $5 \% \mathrm{CO}_{2}$ at $36.5^{\circ} \mathrm{C}$. The removal of endothelial cells was carried
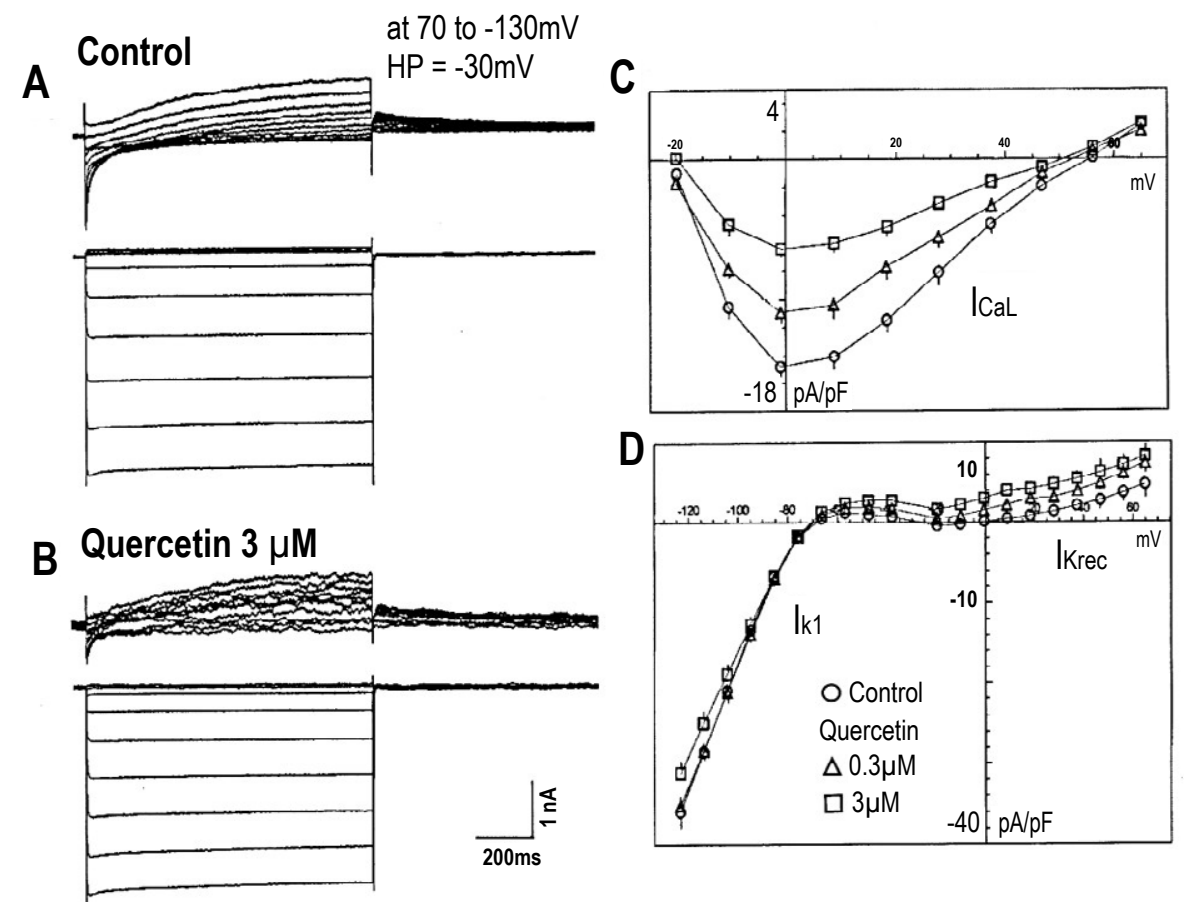

Figure 1: Modulation by quercetin of the ionic currents in guinea pig ventricular cardiomyocytes. A: Control. The test pulses were applied $70 \mathrm{mV}$ and $-130 \mathrm{mV}$ from a holding potential of $-30 \mathrm{mV}$. B: Quercetin $3 \mu \mathrm{M}$. C: Modulation of $\mathrm{I}_{\mathrm{ca}}$ in the absence and the presence of quercetin. Current traces at 30 to $70 \mathrm{mV}$ are superimposed. $\mathrm{D}$ : Modulation of $\mathrm{I}_{\mathrm{K} 1}$ by quercetin. Current traces at -130 to $-30 \mathrm{mV}$ are presented. 
out by usual methods, and the almost absence through microscopy was confirmed after the experiments.

\section{Effects on the endothelial cells}

On endothelium-derived releasing factor (EDRF): Rat aorta exhibited a strong contraction by $5 \mu \mathrm{M}$ NE. Quercetin $(0.1$ to 100 $\mu \mathrm{M})$ subsequently administrated exhibited the marked endotheliumdependent actions (Table 2). Prior administration of L-NMMA $(100 \mu \mathrm{M})$ significantly inhibited the quercetin $(100 \mu \mathrm{M})$-induced vasodilatation from $97.8 \pm 3.7 \%(\mathrm{n}=10)$ to $78.0 \pm 11.6 \%(\mathrm{n}=5, \mathrm{p}<0.05)$. Another NOS inhibitor, L-NAME had the similar effects. This is enforced by the results that removal of endothelium abolished or attenuated the quercetin-induced vasorelaxation. Thus, quercetin decreased the relaxing action by NOS inhibitors. Also, both L-NMMA $(100 \mu \mathrm{M})$ and indomethacin $(10 \mu \mathrm{M})$ attenuated the quercetin-induced vasodilatation more than that with L-NMMA alone.

The endothelium-dependency is important in the quercetininduced vasodilatation. Quercetin causes vasodilatation mainly through NO secretion $[19,20]$, induced by elevating endothelial $\left[\mathrm{Ca}^{2+}\right]_{\mathrm{i}}$ and eNOS phosphorylation $[21,22]$. The $\left[\mathrm{Ca}^{2+}\right]_{i}$ elevation in endothelium facilitates other actions such as a production of hydroxyl hydrogen [23], endothelial hyperpolarization $[24,25]$ induced by activation of $\mathrm{K}_{\mathrm{Ca}}$ channels [26], and production of endothelium-derived hyperpolarizing factor (EDHF) [12,27].

On endothelium-derived hyperpolarizing factor (EDHF): Quercetin increases $\left[\mathrm{Ca}^{2+}\right]_{\mathrm{i}}$ in endothelium, stimulating the synthesis of EDHF [13]. Plant polyphenols have been shown to induce the EDHFtype relaxation [14]. The vasodilatation induced by EDHF is considered to be resistant to both inhibitors of NOS and cyclooxygenase [28]. In the presence of L-NMMA $(100 \mu \mathrm{M})$ and indomethacin $(10 \mu \mathrm{M})$, quercetin at $100 \mu \mathrm{M}$ attenuated by $65.2 \pm 6.6 \%(\mathrm{n}=5, \mathrm{p}<0.001)$ (Table 3 ). In aorta, however, the EDHF-related vasorelaxation is told never to observe [29]. So, we examined using rat mesenteric artery as mentioned in Section 4.2.

On $\mathrm{Ca}^{2+}$-activated $\mathrm{K}^{+}\left(\mathrm{K}_{\mathrm{Ca}}\right)$ channel: The elevation of $\left[\mathrm{Ca}^{2+}\right]_{\mathrm{i}}$ induced by quercetin may stimulate the $\mathrm{K}_{\mathrm{Ca}}$ channel. The activation of $\mathrm{K}_{\mathrm{Ca}}$ channel to hyperpolarize the membrane produces the vasodilatation in rat aorta $[19,30]$. In endothelium-denuded aorta, TEA significantly decreased the quercetin-induced relaxation from $77.9 \pm 2.3 \%$ to 62.5 $\pm 4.9 \%(\mathrm{n}=5, \mathrm{p}<0.05)$. The relaxation involved with KCa channel was examined in the presence of indomethacin and L-NMMA. The L-NMMA/indomethacin-resistant relaxation induced by quercetin $(100 \mu \mathrm{M})$ was significantly reduced by high $\mathrm{K}^{+}(30 \mathrm{mM})$ to $41.0 \pm$ $5.7 \%(\mathrm{n}=5, \mathrm{p}<0.05)$ (Table 3$)$. In high $\mathrm{K}^{+}$solution, furthermore, TEA attenuated the L-NMMA/indomethacin-resistant relaxation to $43.8 \pm$
9.5\% $(\mathrm{n}=5, \mathrm{p}<0.05)$. These results indicate that quercetin modulates the KCa channel.

The $\mathrm{K}_{\mathrm{Ca}}$ channels are classified by their conductances as follows: BK channel (200 pS), IK channel (37 pS), and SK channel (32 pS) [31] TEA is sensitive to all $K_{C}$ channels [32,33], apamine to SK channels [34], and carybdotoxin to BK and IK channels [35]. Apamin $(0.3 \mu \mathrm{M})$, a SK channel inhibitor, strongly decreased the L-NMMA/indomethacinresistant relaxation induced by $30 \mu \mathrm{M}$ quercetin from $30.4 \pm 6.2 \%$ to $9.4 \pm 2.7 \%(\mathrm{n}=5, \mathrm{p}<0.05)$, and from $65.2 \pm 6.6 \%$ to $47.1 \pm 11.4 \%(\mathrm{n}=5$, $\mathrm{p}<0.05)$ by $100 \mu \mathrm{M}$ quercetin. But charybdotoxin $(30 \mathrm{nM})$, a $\mathrm{BK}$ and IK channel inhibitor, had less or no effect. Therefore, quercetin would possess possibly a selective sensitivity to SK channel, but less to BK and IK channels.

On prostaglandin (PG) $\mathbf{I}_{2}$ : The pretreatment with both indomethacin and L-NMMA reduced the relaxation to a greater extent than the pretreatment with L-NMMA alone (but not significantly). The PGI 2 secretion from endothelium may also partly contribute to the relaxation, as reported previously [20]. Therefore, the endotheliumdependent vasorelaxation induced by quercetin is produced due to EDRF and EDHF, and also partly to $\mathrm{PGI}_{2}$.

\section{Effects on vascular smooth muscle}

On L-type $\mathrm{Ca}^{2+}$ channel: L-type $\mathrm{Ca}^{2+}$ channel is regulated by the signal transductions such as cAMP, cGMP and PK-C [15,36,37]. 4- $\beta$-phorbol-12,13-dibutyrate (PDB, a PK-C activator) has small stimulation of the $I_{C a L}$ in $A_{7} R_{5}$ cells [38,39]. Quercetin at $100 \mu \mathrm{M}$ significantly decreased the vasorelaxation from $97.8 \pm 3.7 \%(n=10)$ in normal solution to $67.5 \pm 3.7 \%(\mathrm{n}=5)$ in $\mathrm{Ca}^{2+}$-free solution $(\mathrm{p}<0.01)$ $[7,18]$. The quercetin-induced vasorelaxation was also attenuated by nicardipine, and by a switch from normal Krebs' solution $\left(\mathrm{Ca}^{2+}=1.8\right.$ $\mathrm{mM})$ to $\mathrm{Ca}^{2+}$-free solution. Also, quercetin dilated the $\mathrm{KCl}$-induced vasoconstriction $[3,19]$. These findings demonstrate the vasorelxation due to its $\mathrm{Ca}^{2+}$ channel inhibitory action. Satoh [17] has already reported that quercetin is an inhibitor of $\mathrm{I}_{\mathrm{CaL}}$ channel in cardiomyocytes. These are summarized in Table 3.

On protein kinase C: The $\mathrm{Ca}^{2+}$ mobilization mediated by $\mathrm{PK}-\mathrm{C}$ stimulation might be dependent on kinds of smooth muscles [40]. PDB caused the vasoconstriction. Quercetin possesses the inhibitory actions of PK-C [3,4]. Quercetin at $100 \mu \mathrm{M}$ dilated the PDB $(300$ $\mathrm{nM})$-induced vasoconstriction by $84.8 \pm 6.0 \%(\mathrm{n}=5, \mathrm{p}<0.01)$ (Table 3). Under NE-induced vasoconstriction, staurosporine (100 nM), a PK-C inhibitor, decreased the relaxation induced by $100 \mu \mathrm{M}$ quercetin by approximately $40 \%$. It has been shown that $\mathrm{PK}-\mathrm{Ca}$ and/or $\delta$ are necessary for phorbol ester-mediated constriction of aortic smooth muscle, but are not essential for $\mathrm{NE}-$, vasopressin-, or $\mathrm{K}^{+}$-induced

\begin{tabular}{|c|c|c|c|c|c|c|c|c|}
\hline \multicolumn{9}{|c|}{ Quercetin } \\
\hline & $\mathrm{n}$ & 0.1 & 0.3 & 1 & 3 & 10 & 30 & $100 \mu \mathrm{M}$ \\
\hline Control & 10 & $1.7 \pm 0.5$ & $3.6 \pm 0.9^{1)}$ & $6.9 \pm 0.9^{1)}$ & $12.4 \pm 1.1^{2)}$ & $32.0 \pm 5.7^{2)}$ & $54.1 \pm 8.4^{3)}$ & $97.8 \pm 3.7^{3)}$ \\
\hline Endothelium-denuded & 5 & $1.5 \pm 1.3$ & $3.1 \pm 1.6$ & $6.9 \pm 1.8$ & $11.2 \pm 2.4$ & $30.8 \pm 4.9$ & $44.1 \pm 4.2^{a)}$ & $77.9 \pm 2.3^{a)}$ \\
\hline L-NAME $100 \mu \mathrm{M}$ & 5 & $1.9 \pm 0.9$ & $3.6 \pm 1.1$ & $7.1 \pm 2.1$ & $13.2 \pm 3.7$ & $21.1 \pm 4.6$ & $33.0 \pm 5.3^{a)}$ & $69.5 \pm 6.1^{a)}$ \\
\hline L-NMMA $100 \mu \mathrm{M}$ & 5 & $1.9 \pm 0.6$ & $4.1 \pm 1.3$ & $7.3 \pm 1.8$ & $12.0 \pm 2.4$ & $25.4 \pm 4.8$ & $38.7 \pm 6.0^{a)}$ & $78.0 \pm 11.6^{\mathrm{a})}$ \\
\hline $\begin{array}{c}\text { L-NMMA } 100 \mu \mathrm{M} \\
+ \text { Indomethacin } 10 \mu \mathrm{M}\end{array}$ & 5 & $1.9 \pm 0.8$ & $4.1 \pm 1.3$ & $6.8 \pm 1.3$ & $11.0 \pm 2.0$ & $18.2 \pm 4.7$ & $30.4 \pm 6.2^{a)}$ & $65.2 \pm 6.6^{a)}$ \\
\hline
\end{tabular}

Values (\%) represent mean \pm S.E.M. 1) and a) : $p<0.05,2): p<0.01,3): p<0.001$. Symbols of 1), 2), and 3) mean significant differences in comparison between the effects of quercetin itself at each concentration and the maximal constriction induced by NE. Symbol of a) indicates significant difference as compared with control (quercetin alone) values.

Table 2: Endothelium-dependent vasodilatation induced by quercetin in rat aorta 


\begin{tabular}{|c|c|c|c|c|c|c|c|c|}
\hline \multicolumn{9}{|l|}{ Quercetin } \\
\hline & n & 0.1 & 0.3 & 1 & 3 & 10 & 30 & $100 \mu \mathrm{M}$ \\
\hline \multicolumn{9}{|l|}{ I Constriction induced by Norepinephrine } \\
\hline \multicolumn{9}{|l|}{ A) } \\
\hline Control (Endothelium+) & 10 & $1.7 \pm 0.5$ & $3.6 \pm 0.9^{1)}$ & $6.9 \pm 0.9^{2)}$ & $12.4 \pm 1.1^{2)}$ & $32.0 \pm 5.7^{3)}$ & $54.1 \pm 8.4^{3)}$ & $97.8 \pm 3.7^{3)}$ \\
\hline $\mathrm{Ca} 2+$-free & 5 & $2.1 \pm 1.5$ & $3.1 \pm 1.4$ & $9.0 \pm 2.0$ & $12.8 \pm 3.3$ & $22.6 \pm 2.5$ & $45.0 \pm 3.3^{\mathrm{a})}$ & $67.5 \pm 7.7^{\text {a) }}$ \\
\hline Nicardipine & 5 & $0.0 \pm 0.0$ & $1.4 \pm 1.4$ & $1.4 \pm 1.4$ & $1.4 \pm 1.4^{\text {a) }}$ & $6.8 \pm 3.6^{\mathrm{a})}$ & $15.0 \pm 7.2^{\mathrm{a})}$ & $61.2 \pm 16.6^{\text {a) }}$ \\
\hline 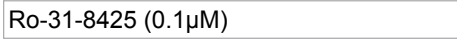 & 5 & $1.5 \pm 1.0$ & $3.0 \pm 1.9$ & $6.6 \pm 2.5$ & $12.8 \pm 4.0$ & $23.0 \pm 4.9$ & $42.8 \pm 4.2^{\mathrm{a})}$ & $80.8 \pm 2.6^{\text {b) }}$ \\
\hline Gö6983 $(0.1 \mu \mathrm{M})$ & 5 & $1.0 \pm 0.6$ & $2.0 \pm 1.2$ & $2.8 \pm 1.7$ & $8.1 \pm 2.5$ & $18.8 \pm 3.5$ & $40.0 \pm 6.2^{\mathrm{a})}$ & $84.6 \pm 7.7^{\text {a) }}$ \\
\hline \multicolumn{9}{|l|}{ B) } \\
\hline Endothelium-denuded & 5 & $1.5 \pm 1.3$ & $3.1 \pm 1.6$ & $6.9 \pm 1.8$ & $11.2 \pm 2.4^{1)}$ & $30.8 \pm 4.9^{2)}$ & $44.1 \pm 4.2^{2)}$ & $77.9 \pm 2.3^{3)}$ \\
\hline$+\mathrm{TEA}(100 \mu \mathrm{M})$ & 5 & $1.0 \pm 0.75$ & $3.0 \pm 1.3$ & $5.5 \pm 2.6$ & $9.2 \pm 3.6$ & $17.9 \pm 4.2^{\mathrm{a})}$ & $31.7 \pm 4.9^{a)}$ & $62.5 \pm 4.9^{a)}$ \\
\hline \multicolumn{9}{|l|}{ C) } \\
\hline L-NMMA $(100 \mu M)+$ Indomethacin $(10 \mu M)$ & 5 & $1.9 \pm 0.8$ & $4.1 \pm 1.3$ & $6.8 \pm 1.3^{1)}$ & $11.0 \pm 2.0^{2}$ & $18.2 \pm 4.7^{2)}$ & $30.4 \pm 6.2^{3)}$ & $65.2 \pm 6.6^{3)}$ \\
\hline +high $\mathrm{K}+(30 \mathrm{mM})$ & 5 & $0.5 \pm 0.3$ & $2.6 \pm 1.5$ & $5.1 \pm 1.6$ & $9.4 \pm 2.3$ & $13.6 \pm 1.9$ & $24.4 \pm 3.9^{\text {a) }}$ & $41.0 \pm 5.7^{\mathrm{a})}$ \\
\hline+ TEA $(100 \mu \mathrm{M})$ & 5 & $1.2 \pm 0.5$ & $1.8 \pm 1.5$ & $1.8 \pm 1.5$ & $4.0 \pm 4.0$ & $8.5 \pm 5.5$ & $16.8 \pm 7.0^{\mathrm{a})}$ & $43.8 \pm 9.5^{a)}$ \\
\hline +Charybdotoxin & 5 & $2.1 \pm 1.3$ & $3.8 \pm 2.6$ & $4.2 \pm 2.0$ & $4.5 \pm 2.3$ & $16.8 \pm 3.6$ & $28.2 \pm 2.7$ & $63.4 \pm 11.8$ \\
\hline +Apamin & 5 & $0.6 \pm 0.6$ & $0.8 \pm 0.8$ & $1.6 \pm 1.6$ & $3.7 \pm 2.7$ & $5.1 \pm 1.6$ & $9.4 \pm 2.4^{b)}$ & $47.1 \pm 11.1^{\mathrm{b})}$ \\
\hline \multicolumn{9}{|l|}{ II Constriction induced by KCL } \\
\hline \multicolumn{9}{|l|}{ A) } \\
\hline Control & 10 & $0.0 \pm 0.0$ & $0.8 \pm 0.4$ & $0.9 \pm 0.4$ & $0.9 \pm 0.4$ & $8.8 \pm 2.2^{1)}$ & $29.9 \pm 6.0^{2)}$ & $92.8 \pm 4.0^{3)}$ \\
\hline 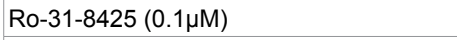 & 5 & $0.0 \pm 0.0$ & $0.0 \pm 0.0$ & $0.3 \pm 0.3$ & $1.0 \pm 0.6$ & $9.6 \pm 3.1$ & $16.0 \pm 3.1^{\text {a) }}$ & $75.6 \pm 7.9^{\text {a) }}$ \\
\hline Gö6983 $(0.1 \mu \mathrm{M})$ & 5 & $0.0 \pm 0.0$ & $1.0 \pm 1.0$ & $1.1 \pm 1.0$ & $1.4 \pm 1.2$ & $8.0 \pm 1.2$ & $26.8 \pm 2.8$ & $49.5 \pm 13.7^{\text {a) }}$ \\
\hline
\end{tabular}

Values (\%) represent mean \pm S.E.M. ${ }^{1)}$ and ${ }^{\text {a) }}: p<0.05,{ }^{2)}$ and ${ }^{\text {b) }}: p<0.01,{ }^{3)}: p<0.001$

I: A) The symbols of $\mathrm{a}), \mathrm{b}$ ) indicate significant difference as compared with control (endothelium (+)) values. B) The symbol of ${ }^{\text {a) }}$ indicate indicates significant difference as compared with endothelium-denuded. C) The symbol of a), b) indicates significant difference as compared with L-NAME+indomethacin. II : A) Symbols of 1), 2), and 3) mean significant differences in comparison between effects of quercetin itself at each concentration and the maximal constriction induced by $\mathrm{KCl}$. The symbol of a) indicates significant difference as compared with control (quercetin alone) values.

Table 3: The alteration of endothelium-independent vasodilatation induced by quercetin in rat aorta.

constriction [41]. Furthermore, PK-Ca and $\delta$ isozymes are dominant in cultured rat aortic vascular smooth muscle cell, and both isozymes are completely down-regulated by prolonged (16-24 hr) stimulation with the PK-C activator [42]. PK-C $\varepsilon$ can modulate phenylephrineinduced contraction in mesenteric artery via calcium-independent pathways [43].

To examine which subtypes of PK-C are related with the quercetininduced constriction, two different types of PK-C inhibitors were chosen; Gö6983 sensitive to $\alpha, \beta, \gamma, \delta$ and $\zeta$ isozymes, and Ro-318425 to $\alpha, \beta, \gamma$ and $\varepsilon$ isozymes of of PK-C [44]. Ro-31-8425 (0.1 $\mu \mathrm{M})$ attenuated the quercetin $(100 \mu \mathrm{M})$-induced vasorelaxation by 80.8 $\pm 2.6 \%(\mathrm{n}=5, \mathrm{p}<0.001)$. Gö6983 $(0.1 \mu \mathrm{M})$, also had similar effects by $84.6 \pm 7.6 \%(\mathrm{n}=5, \mathrm{p}<0.001)$. Under the $\mathrm{KCl}$-induced vasoconstriction, both Gö6983 and Ro-31-8425 attenuated the quercetin $(100 \mu \mathrm{M})$ induced vasorelaxation by $49.5 \pm 7.9 \%(\mathrm{n}=5, \mathrm{p}<0.01)$ and by $75.5 \pm$ $7.9 \%(\mathrm{n}=5, \mathrm{p}<0.001)$, respectively (Table 3$)$. Thus, quercetin might inhibit possibly mediated through $\mathrm{PK}-\mathrm{C} \delta$, although it is still difficult to clearly distinguish. In addition, PK-C phosphrylates tyrosin kinase and vasodilator-stimulated phosphoprotein (VASP) as a substrate of cGMP-dependent protein kinase (cGMP-PK) [45]. In this study, however, genistein (tyrosine kinase inhibitor) at $50 \mu \mathrm{M}$ failed to affect the quercetin-induced constriction (by just $0.7 \%$ decrease). The activation of MLCK is abolished by PK-C $[40,46]$. Furthermore, quercetin inhibits the phosphorylation of mitogen-activated protein kinases (MAPKs); extracellular signal-regulated kinase (ERK) 1/2, p38 MAPK, and c-jun amino-terminal kinase (JNK) in cultured aortic cells and phosphatidylinositol 3-kinase ( $\mathrm{PI}_{3}$-kinase)/protein kinase B (Akt) $[47,48]$.

On $\mathrm{Ca}^{2+}$-activated $\mathrm{K}^{+}\left(\mathrm{K}_{\mathrm{Ca}}\right)$ channels: Flavonoids have been shown to produce vasodilatation due to the $\mathrm{K}_{\mathrm{Ca}}$ channel to hyperpolarize the membrane of vascular smooth muscle $[30]$. The $\left[\mathrm{Ca}^{2+}\right]_{\mathrm{i}}$ in smooth muscle cells initially increases, and then, facilitates the other physiological actions. The vasorelaxation of quercetin is also due to $\mathrm{K}_{\mathrm{Ca}}$ activation involved with EDHF [9]. Recently, quercetin has been demonstrated to activate $\mathrm{BK}$ channel in coronary arteries via production of $\mathrm{H}_{2} \mathrm{O}_{2}$ [49]. In addition, glibenclamide (a $\mathrm{K}_{\text {ATP }}$ channel inhibitor) have not been reported to affect the quercetin-induced vasodilatation in rat aorta [9]. Anyway, the vasodilatation is responsible for SK channel activation (though not distinguish in endothelium or smooth muscle cells) (Table $3)$.

Summary: The vasodilation mechanisms in rat aorta were due to the inhibitions of (1) NOS by L-NMMA or L-NAME and removal of endothelium, (2) $\mathrm{I}_{\mathrm{CaL}}$ by $\mathrm{Ca}^{2+}$ antagonist, in $\mathrm{Ca}^{2+}$ free solution and under the $\mathrm{KCl}$ constriction, (3) PK-C activation mediated through possibly the PK-C $\delta$ subtype, and (4) $\mathrm{K}_{\mathrm{Ca}}$ channel by apamin but not by charybdotoxin. Furthermore, the vasodilation was produced by (5) both L-NMMA and indomethacin, (6) L-NMMA and indomethacin plus TEA during exposure to high $\mathrm{K}^{+}$solution, and (7) TEA in endothelium-denuded aorta (Figure 2). Therefore, quercetin's effect is due to endothelium-dependent actions mediated through the NO (EDRF), EDHF and partly PGI $_{2}$ syntheses. As well it is due to endothelium-independent actions mediated through the $\mathrm{Ca}^{2+}$ channel, the $\mathrm{K}_{\mathrm{Ca}}$ channels selective to SK channel, and PK-C $[7,18]$.

\section{Vasodilating Effects on Rat Mesenteric Artery}

For this investigation, the similar methods to rat aorta experiments were performed. Mesenteric artery was removed from the same Wistar male rats $[18,19]$. The isolated mesenteric artery was cut into $1 \mathrm{~mm}$ rings in length, suspended between two stainless steel stirrups in a bath filled with modified Krebs-Henseleit solution. The isometric force was recorded using the force-displacement transducer (UL-10GR, Minebea Co., Tokyo, Japan). Rat mesenteric artery also caused the contraction by an application of $1 \mu \mathrm{MNE}$. Quercetin $(0.1-100 \mu \mathrm{M})$ caused the significant 
vasodilatation in a concentration-dependent manner; at $100 \mu \mathrm{M}$, the vasodilatation was $99.6 \pm 3.0 \%(\mathrm{n}=10, \mathrm{p}<0.001)$. The quercetin-induced vasodilatation was almost consistent with the results in rat aorta [50]. But it was weaker blockade than the results in rat aorta (Table 4). Similarly both L-NAME $(100 \mu \mathrm{M})$ and indomethacin $(100 \mu \mathrm{M})$ failed to cause a remarkable change in the quercetin-induced vasodilatation, as compared with that with L-NAME alone. Endothelium-denuded arteries also contracted at $1 \mu \mathrm{M}$ NE. Endothelium removal strongly decreased the quercetin-induced vasodilatation; at $100 \mu \mathrm{M}$ quercetin by $77.9 \pm 2.4 \%(\mathrm{n}=6, \mathrm{p}<0.01)$. Furthermore, endothelium-removal more strongly reduced the quercetin-induced vasodilatation in the presence of L-NAME and indomethacin, indicating that the relaxation is independent of endothelium. Thus, NO may play a minor role for the quercetin-induced vasodilatation in mesenteric artery, different from aorta.

\section{On $\mathrm{K}_{\mathrm{Ca}}$ channel}

The L-NAME/indomethacin-resistant (NO/prostaglandinindependent) relaxation induced by quercetin was never affected by $100 \mu \mathrm{M}$ TEA (Table 4). Increasing TEA concentration to $1 \mathrm{mM}$ tended to be reduced the resistant vasodilation at 10 to $30 \mu \mathrm{M}$ quercetin, but not significantly. At $100 \mu \mathrm{M}$ quercetin, TEA $(1 \mathrm{mM})$ was almost identical to the L-NAME/indomethacin-resistant vasodilatation $(82.3$ $\pm 2.6, \mathrm{n}=8, \mathrm{p}<0.001$ ) [50]. Since quercetin stimulates SK channel in rat aorta [19], quercetin would similarly activate SK channel in mesenteric artery.

\section{On endothelium-derived hyperpolarizing factor (EDHF)}

Since the contribution to EDHF-related vasorelaxation is told never to observe in aorta [29], the experiments using rat mesenteric artery were performed. The hyperpolarization induced by EDHF makes the membrane stable, and depresses the ionic channel activity related to the vasoconstriction. The quercetin-induced relaxation in the presence of indomethacin and L-NMMA was reduced by high $\mathrm{K}^{+}$or TEA. Apamin inhibited the quercetin-induced vasorelaxation. These findings strongly demonstrate that the quercetin-induced vasorelaxation is closely involved with EDHF. Therefore, it is possible that quercetin may increases $\left[\mathrm{Ca}^{2+}\right]_{\mathfrak{i}}$, and then facilitates EDHF synthesis as well as NOS in endothelium.

In rat mesenteric artery, quercetin actually produces NO from endothelium. However, endothelium removal attenuated the quercetin-induced vasodilatation to a greater extent than both L-NAME and indomethacin (Table 4). This strongly demonstrates that the endothelium of mesenteric artery plays an important role in the quercetin-induced vasodilatation, mainly dependent on EDHF rather than NO. In resistant vessels than aorta, the EDHF-type relaxation is relatively more predominant [29]. ACh causes the EDHF-type relaxation mediated through $\mathrm{K}_{\mathrm{Ca}}$ channels in fetal aorta [51]. L-NAME attenuated (though be a weak blockade) the quercetin-induced vasodilatation. Thus, $\mathrm{NO}$ plays a minor role for the quercetin-induced vasodilatation of mesenteric artery. As well, it may be considered that quercetin is responsible for EDHF-type relaxation, which which is attenuated by high $\mathrm{K}+$ or TEA [32,52]. Moreover, the EDHF-type relaxation is attenuated by bothapamin and charybdotoxin [53].

EDHF hyperpolarizes to dilate smooth muscle cells. Some candidates for EDHF have already been shown: $\mathrm{K}^{+}[52,53]$, epoxyeicosatrienoic acids (EETs) [52,54], and $\mathrm{H}_{2} \mathrm{O}_{2}$ derived from endothelium [23]. In our studies, two mechanisms for the EDHF-induced hyperpolarization have been inferred: (1) EDHF hyperpolarizes smooth muscle cells by stimulating $\mathrm{K}_{\mathrm{Ca}}$ channels $[13,28]$, and (2) the EDHF-mediated response is due to gap junctions, which is confirmed by the electrical communications between endothelium and smooth muscle cells $[27,52]$. Furthermore, the gap junction for EDHF-type relaxation has already identified by using antibody analysis $[55,56]$.

\section{On gap junction}

In our experiments, the quercetin-induced relaxation in the presence of indomethacin and L-NAME was not reduced by high TEA $(1 \mathrm{mM})$. Additional pretreatment with $100 \mu \mathrm{M} 18 \alpha-$ or $50 \mu \mathrm{M}$ $18 \beta$-glychrrhetinic acids (18 $\alpha$ - and $18 \beta$-GAs) significantly inhibited the L-NAME/indomethacin-resistant vasodilatation from $82.0 \pm 2.4 \%$ $(\mathrm{n}=6)$ to $63.3 \pm 5.5 \%(\mathrm{n}=9, \mathrm{p}<0.01)$ (Table 4$) .18 \alpha$ - and $18 \beta$-GAs are the selective blockers of gap junctions [57]. Endothelium removal also attenuated the quercetin-induced vasodilatation to the same extent as the presence of the inhibitors such as L-NAME, indomethacin, and $18 \alpha-$ and $18 \beta$-GAs. So, these findings indicate that the gap junctions contribute to the quercetin-induced vasodilatation. Both $18 \alpha-$ and $18 \beta$-GAs reduced the quercetin-induced vasodilatation to a greater extent, as compared with the effect of TEA.

The discrepancy between the results of TEA and $18 \alpha-$ and $18 \beta-G A s$ might be due to both mechanisms: (1) quercetin elevates endothelial $\left[\mathrm{Ca}^{2+}\right]_{\mathrm{i}}$ and then, activates $\mathrm{K}_{\mathrm{Ca}}$ channels, and (2) quercetin itself has a stimulatory actions on $\mathrm{K}_{\mathrm{Ca}}$ channels. The elevation of $\left[\mathrm{Ca}^{2+}\right]_{\mathrm{i}}$ induced by quercetin activates SK channels [19] to hyperpolarize the endothelium $[58,59]$. Quercetin would activate SK channel in endothelium via both

\begin{tabular}{|c|c|c|c|c|c|c|c|c|}
\hline \multicolumn{9}{|c|}{ Quercetin } \\
\hline & $\mathrm{n}$ & 0.1 & 0.3 & 1 & 3 & 10 & 30 & $100 \mu \mathrm{M}$ \\
\hline $\begin{array}{c}\text { Control } \\
\text { A }\end{array}$ & 10 & $1.6 \pm 0.94$ & $8.0 \pm 1.7^{1)}$ & $23.4 \pm 3.2^{2)}$ & $33.9 \pm 2.7^{2)}$ & $55.5 \pm 3.2^{3)}$ & $69.8 \pm 3.4^{3)}$ & $99.6 \pm 3.0^{3)}$ \\
\hline Endothelium-denuded & 6 & $1.8 \pm 0.55$ & $3.8 \pm 1.6^{b)}$ & $8.5 \pm 1.9^{b)}$ & $13.0 \pm 2.6^{b)}$ & $30.8 \pm 4.9^{(b)}$ & $44.2 \pm 4.2^{\mathrm{b})}$ & $77.9 \pm 2.4^{b)}$ \\
\hline L-NAME $100 \mu \mathrm{M}$ & 8 & $1.3 \pm 0.9$ & $3.2 \pm 1.8$ & $19.2 \pm 3.4$ & $31.0 \pm 2.8$ & $51.2 \pm 2.0$ & $62.3 \pm 4.7$ & $86.0 \pm 7.0^{\mathrm{a})}$ \\
\hline \multicolumn{9}{|l|}{ B } \\
\hline L-NAME+Indomethacin $(100 \mu \mathrm{M})$ & 8 & $1.9 \pm 0.75$ & $4.1 \pm 1.3$ & $19.0 \pm 7.3$ & $31.2 \pm 6.3$ & $52.5 \pm 7.8$ & $63.2 \pm 6.9$ & $82.0 \pm 2.2$ \\
\hline$+\mathrm{TEA}(100 \mu \mathrm{M})$ & 6 & $1.3 \pm 0.80$ & $7.5 \pm 2.9$ & $20.2 \pm 5.7$ & $32.0 \pm 3.0$ & $52.5 \pm 2.6$ & $67.8 \pm 2.4$ & $82.0 \pm 2.4$ \\
\hline +glycyrrhetinic acids & 9 & $2.2 \pm 1.3$ & $5.5 \pm 2.8$ & $11.5 \pm 5.0$ & $20.5 \pm 5.3$ & $35.0 \pm 6.0^{a)}$ & $51.1 \pm 4.3^{a)}$ & $63.3 \pm 5.5^{b)}$ \\
\hline
\end{tabular}

Values (\%) represent mean \pm S.E.M. 1) and ${ }^{a)}: p<0.05,{ }^{2)}$ and $\left.{ }^{b)}: p<0.01,3\right): p<0.001$.

Symbols of $\left.{ }^{1)}, 2\right)$, and ${ }^{3)}$ mean significant differences in comparison between effects of quercetin itself at each concentration and the maximal contraction induced by NE. A) The symbol of a), b) indicate significant difference as compared with control (quercetin alone) values. B) The symbol of a), b) indicate significant difference as compared with L-NAME and indomethacin.

Table 4: Modulation of endothelium-dependent relaxation induced by quercetin in rat mesenteric artery. 


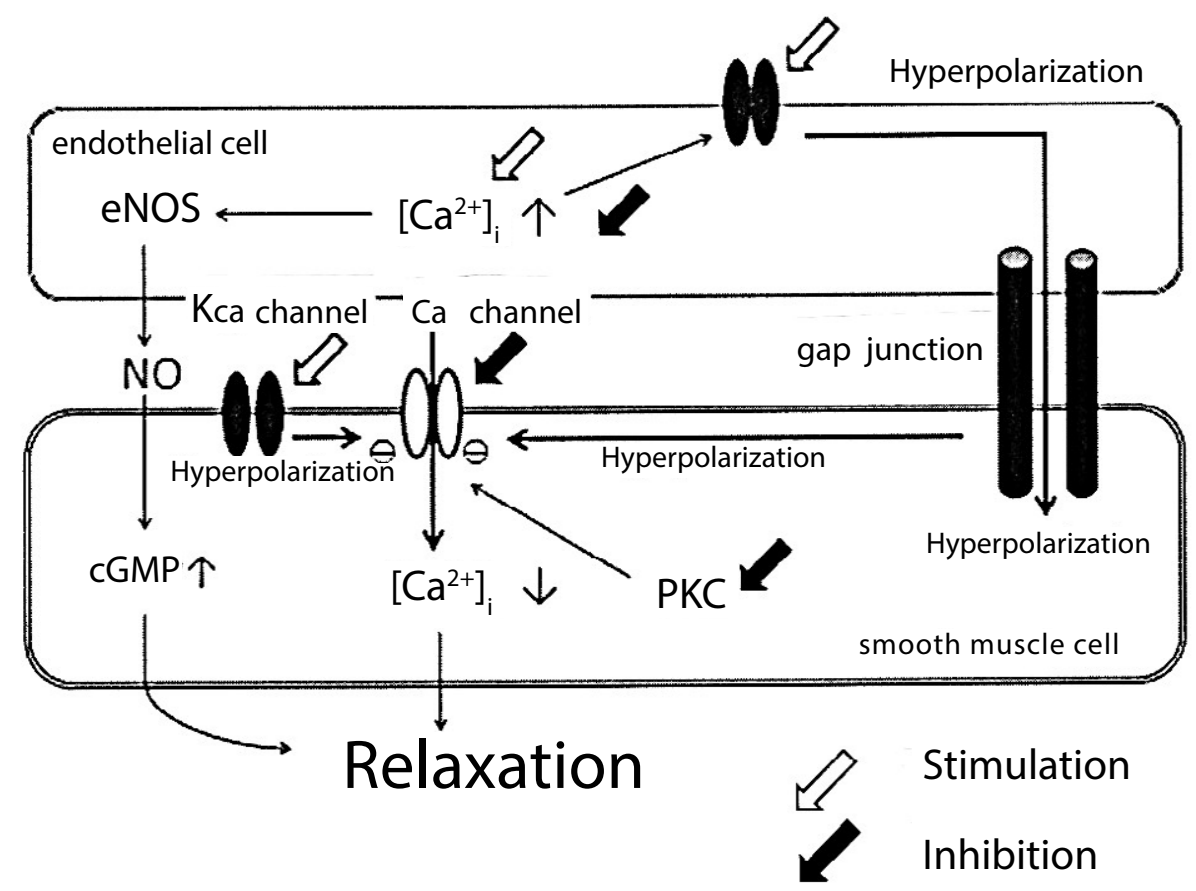

Figure 2: Diagram for the mechanism of quecetin-induced vasorelaxation. Quercetin induces $\left[\mathrm{Ca}^{2+}\right]_{\mathrm{i}}$ elevation, leading to NO production and $\mathrm{K}_{\mathrm{Ca}}$ channel activation in endothelium cell. The hyperpolarization induced by the activation of $\mathrm{K}_{\mathrm{Ca}}$ channel inhibits $\mathrm{Ca}^{2+}$ channel in smooth muscle cell. Moreover, modulation of gap junction aggravates the vasodilatation.

mechanisms. Thus, TEA failed to inhibit $\mathrm{K}_{\mathrm{Ca}}$ channels in endothelium. Although the effect of TEA on the quercetin-induced vasodilatation is affected by both mechanisms, the transduction of the endothelial hyperpolarization to smooth muscle cells is blocked by $18 \mathrm{a}-$ and $18 \beta$-GAs, and also the endothelial removal. Therefore, the gap junctions involved with EDHF would be responsible for the quercetin-induced vasodilatation [50].

\section{Summary}

Rat mesenteric artery possesses almost the similar characteristics to the aorta (Figure 2); (1) quercetin caused a concentrationdependent vasodilatation, (2) the quercetin-induced vasodilation was attenuated by L-NAME, (3) the addition of indomethacin did not cause further modifications, (4) TEA $(1 \mathrm{mM})$ tended to reduce L-NAME/ indomethacin-resistant vasodilatation, (5) at high concentrations (100 $\mu \mathrm{M})$ of quercetin, TEA failed to produce any effects on L-NAME/ indomethacin-resistant vasodilatation, (6) L-NAME/indomethacinresistant vasodilatation was reduced by $18 \alpha-$ and $18 \beta$-GAs, (7) endothelium removal strongly attenuated the quercetin-induced vasodilatation, and (8) $18 \alpha$ - and $18 \beta$-GAs reduced the quercetininduced vasodilatation to the same significant extent as the endothelium removal.

The vasodilatation in rat mesenteric artery is also endotheliumdependent. Quercetin produces NO in endothelium, but plays minor role in the quercetin-induced vasodilatation. The vasodilatation induced by quercetin is mainly due to the gap junctions, closely involved with EDHF.

\section{References}

1. Manach C, Morand C, Texier O, Favier ML, Agullo G, et al. (1995) Quercetin metabolites in plasma of rats fed diets containing rutin or quercetin. J Nutr 125: 1911-1922.

2. Erlund I, Silaste ML, Alfthan G, Rantala M, Kesäniemi YA, et al. (2002) Plasma concentrations of the flavonoids hesperetin, naringenin and quercetin in human subjects following their habitual diets, and diets high or low in fruit and vegetables. Eur J Clin Nutr 56: 891-898.

3. Duarte J, Pérez-Vizcaíno F, Zarzuelo A, Jiménez J, Tamargo J (1993) Vasodilator effects of quercetin in isolated rat vascular smooth muscle. Eur $\mathrm{J}$ Pharmacol 239: 1-7.

4. Murota K, Terao J (2003) Antioxidative flavonoid quercetin: implication of its intestinal absorption and metabolism. Arch Biochem Biophys 417: 12-17.

5. Hertog MG, Feskens EJ, Hollman PC, Katan MB, Kromhout D (1993) Dietary antioxidant flavonoids and risk of coronary heart disease: the Zutphen Elderly Study. Lancet 342: 1007-1011.

6. Satoh H (2003) Effects of ginkgo biloba extract and bilobalide, a main constituent, on the ionic currents in guinea pig ventricular cardiomyocytes. Arzneimittelforschung 53: 407-413.

7. Satoh H, Nishida S (2004) Electropharmacological actions of Ginkgo biloba extract on vascular smooth and heart muscles. Clin Chim Acta 342: 13-22.

8. Satoh H, Nishida S (2010) Cardiovascular pharmacology of Ginkgo biloba extract and its constituents. Basics of Evidences-Based Herbal Medicine. Signpost, Kerala, India, pp. 37-58.

9. Pérez-Vizcaíno F, Ibarra M, Cogolludo AL, Duarte J, Zaragozá-Arnáez F, et al (2002) Endothelium-Independent Vasodilator effects of the flavonoid quercetin and its methylated metabolites in rat conductance and resistance arteries. $J$ Pharmacol Exp Ther 302: 66-72.

10. Kuhlmann CR, Schaefer CA, Kosok C, Abdallah Y, Walther S, et al. (2005) Quercetin-induced vasodilatation of the NO/cGMP pathway depends on $\mathrm{Ca}^{2+}$ activated $\mathrm{K}^{+}$channel-induced hyperpolarization-mediated $\mathrm{Ca} 2+$ entry into cultured human endothelial cells. Planta Medica 6: 520-524.

11. Mayer B, Schmidt K, Humbert P, Böhme E (1989) Biosynthesis of endotheliumderived relaxing factor: a cytosolic enzyme in porcine aortic endothelial cells $\mathrm{Ca}^{2+}$-dependently converts L-arginine into an activator of soluble guanylate cyclase. Biochem. Biophys Res Commun 164: 678-685.

12. Chen GF, Suzuki H (1990) Calcium dependency of the endothelium-dependent hyperpolarization in smooth muscle cells of the rabbit carotid artery. J Physiol 421: 521-534.

13. Félétou M, Vanhoutte PM (2002) The Alternative: EDHF. J Mol Cell Cardiol 31: $15-22$. 
14. Ndiaye M, Chataigneau T, Andriantsitohaina R, Stoclet JC, Schini-Kerth VB (2003) Red wine polyphenols cause endothelium-dependent EDHF-mediated relaxations in porcine coronary arteries via a redox-sensitive mechanism. Biochem Biophys Res Commun 310:371-7.

15. Satoh $\mathrm{H}$ (1996) Enhancement of $\mathrm{K}^{+}$currents by stimulation of protein kinase $\mathrm{C}$ in the uterine smooth muscle cells of the pregnant rat. Gen Pharmacol 27: 455-458.

16. Satoh $H$ (1996) Modulation of $\mathrm{Ca}(2+)$-activated $\mathrm{K}+$ current by isoprenaline, carbachol, and phorbol ester in cultured (and fresh) rat aortic vascular smooth muscle cells. Gen Pharmacol 27: 319-324.

17. Satoh H (2004) Comparative Electropharmacological Actions of Some Constituents from Ginkgo biloba Extract in Guinea-pig Ventricular Cardiomyocytes. Evid Based Complement Alternat Med 1: 277-284.

18. Nishida S, Satoh $\mathrm{H}$ (2004) Comparative vasodilating actions among terpenoids and flavonoids contained in Ginkgo biloba extract. Clin Chim Acta 339: 129133

19. Nishida S, Satoh H (2009) Possible Involvement of Ca Activated K Channels, SK Channel, in the Quercetin-Induced Vasodilatation. Korean J Physio Pharmacol 13: 361-365.

20. Ajay M, Gilani AU, Mustafa MR (2003) Effects of flavonoids on vascular smooth muscle of the isolated rat thoracic aorta. Life Sci 74: 603-612.

21. Khoo NK, White CR, Pozzo-Miller L, Zhou F, Constance C, et al. (2010) Dietary flavonoid quercetin stimulates vasorelaxation in aortic vessels. Free Radic Bio Med 49: 339-347.

22. Li PG, Sun L, Han X, Ling S, Gan WT, et al. (2012) Quercetin induces rapid eNOS phosphorylation and vasodilation by an Akt-independent and PKAdependent mechanism. Pharmacology 89: 220-228.

23. Matoba T, Shimokawa H, Nakashima M, Hirakawa Y, Mukai Y, et al. (2000) Hydrogen peroxide is an endothelium-derived hyperpolarizing factor in mice. $J$ Clin Invest 106: 1521-1530.

24. Busse R, Fichtner H, Lückhoff A, Kohlhardt M (1988) Hyperpolarization and increased free calcium in acetylcholine-stimulated endothelial cells. Am Physiol 255: H965-969.

25. Vaca L, Licea A, Possani LD (1996) Modulation of cell membrane potential in cultured vascular endothelium. Am J Physiol 270: C819-824.

26. Dora KA, Gallagher NT, McNeish A, Garland CJ (2008) Modulation of endothelial cell $\mathrm{KCa} 3.1$ channels during endothelium-derived hyperpolarizing factor signaling in mesenteric resistance arteries. Circ Res 102: 1247-1255.

27. Ungvari Z, Csiszar A, Koller A (2002) Increases in endothelial $\mathrm{Ca}(2+)$ activate $\mathrm{K}(\mathrm{Ca})$ channels and elicit EDHF-type arteriolar dilation via gap junctions. Am J Physiol Heart Circ Physiol 282: H1760-1767.

28. Fukao M, Hattori Y, Kanno M, Sakuma I, Kitabatake A (1997) Sources of Ca2+ in relation to generation of acetylcholine-induced endothelium-dependent hyperpolarization in rat mesenteric artery. Br J Pharmacol 120: 1328-1334.

29. Woodman OL, Wongsawatkul O, Sobey CG (2000) Contribution of nitric oxide cyclic GMP and K+ channels to acetylcholine-induced dilatation of rat conduit and resistance arteries. Clin Exp Pharmacol Physiol 27: 34-40.

30. Calderone V, Chericoni S, Martinelli C, Testai L, Nardi A, et al. (2004) Vasorelaxing effects of flavonoids: investigation on the possible involvement of potassium channels. Naunyn Schmiedebergs Arch Pharmacol 370: 290-298.

31. Brayden JE, Nelson MT (1992) Regulation of arterial tone by activation of calcium-dependent potassium channels. Science 256: 532-535.

32. Chen G, Yamamoto Y, Miwa K, Suzuki H (1991) Hyperpolarization of arterial smooth muscle induced by endothelial humoral substances. Am J Physiol 260: H1888-1892.

33. Hill CE, Hickey H, Sandow SL (2000) Role of gap junctions in acetylcholineinduced vasodilation of proximal and distal arteries of the rat mesentery. $J$ Auton Nerv Syst 81: 122-127.

34. Maylie J, Bond CT, Herson PS, Lee WS, Adelman JP (2004) Small conductance Ca2+-activated K+ channels and calmodulin. J Physiol 554: 255-261.

35. Neylon CB, Lang RJ, Fu Y, Bobik A, Reinhart PH (1999) Molecular cloning and characterization of the intermediate-conductance $\mathrm{Ca}(2+)$-activated $\mathrm{K}(+)$ channel in vascular smooth muscle: relationship between $\mathrm{K}(\mathrm{Ca})$ channel diversity and smooth muscle cell function. Circ Res 85: e33-43.

36. Satoh H (1995) Depression of the spontaneous activity by phorbol esters in young embryonic chick cardiomyocytes. Jpn J Pharmacol 67: 297-304.
37. Satoh H, Hashimoto K (1988) On electrophysiological responses to phorbol esters which stimulate protein kinase $\mathrm{C}$ in rabbit sino-atrial node cells. Naunyn Schmiedebergs Arch Pharmacol 337: 308-315

38. Satoh H, Sperelakis N (1991) Calcium and potassium currents in cultured in rat aortic vascular smooth muscle cell lines, Ion Channels of Vascular Smooth Muscle Cells and Endothelial Cells. Academic Press, New York, USA, pp.5563.

39. Satoh H, Sperelakis N (1995) Modulation of L-type Ca2+ current by isoprenaline, carbachol and phorbol ester in cultured rat aortic vascular smooth muscle (A7r5) cells. Gen Pharmacol 26: 369-379.

40. Murthy KS, Grider JR, Kuemmerle JF, Makhlouf GM (2000) Sustained muscle contraction induced by agonists, growth factors, and $\mathrm{Ca}(2+)$ mediated by distinct PKC isozymes. Am J Physiol Gastrointest Liver Physiol 279: G201-210.

41. Ohanian V, Ohanian J, Shaw L, Scarth S, Parker PJ, et al. (1996) Identification of protein kinase $\mathrm{C}$ isoforms in rat mesenteric small arteries and their possible role in agonist-induced contraction. Circ Res 78: 806-812.

42. Busuttil SJ, Morehouse DL, Youkey JR, Singer HA (1996) Antisense suppresssion of protein kinase $\mathrm{C}$-alpha and -delta in vascular smooth muscle. J Surg Res 63: 137-142.

43. Shirasawa Y, Rutland TJ, Young JL, Dean DA, Joseph BN (2003) Modulation of protein kinase $C$ (PKC)-mediated contraction and the possible role of PKC epsilon in rat mesenteric arteries. Front Biosci 8: a133-138.

44. Zhu S, White RE, Barman SA (2006) Effect of PKC isozyme inhibition on forskolin-induced activation of BKCa channels in rat pulmonary arterial smooth muscle. Lung 184: 89-97.

45. Wentworth JK, Pula G, Poole AW (2006) Vasodilator-stimulated phosphoprotein (VASP) is phosphorylated on Ser157 by protein kinase C-dependent and -independent mechanisms in thrombin-stimulated human platelets. Biochem J 393: 555-564.

46. Hagiwara M, Inoue S, Tanaka T, Nunoki K, Ito M, et al. (1988) Differentia effects of flavonoids as inhibitors of tyrosine protein kinases and serine/ threonine protein kinases. Biochem Pharmacol 37: 2987-2992.

47. Shih CM, Lin H, Liang YC, Lee WS, Bi WF, et al. (2004) Concentrationdependent differential effects of quercetin on rat aortic smooth muscle cells. Eur J Pharmacol 496: 41-48.

48. Lin CW, Hou WC, Shen SC, Juan SH, Ko CH, et al. (2008) Quercetin inhibition of tumor invasion via suppressing PKC delta/ERK/AP-1-dependent matrix metalloproteinase- 9 activation in breast carcinoma cells. Carcinogenesis 29 . 1807-1815.

49. Cogolludo A, Frazziano G, Briones AM, Cobeño L, Moreno L, et al. (2007) The dietary flavonoid quercetin activates $\mathrm{BKCa}$ currents in coronary arteries via production of $\mathrm{H} 2 \mathrm{O} 2$. Role in vasodilatation. Cardiovasc Res 73: 424-431.

50. Nishida S, Satoh H (2013) Role of gap junction involved with endotheliumderived hyperpolarizing factor for the quercetin-induced vasodilatation in rat mesenteric artery. Life Sci 92: 752-756.

51. Martínez-Orgado J, González R, Alonso MJ, Marín J (1999) Nitric oxidedependent and -independent mechanisms in the relaxation elicited by acetylcholine in fetal rat aorta. Life Sci 64: 269-277.

52. Campbell WB, Gebremedhin D, Pratt PF, Harder DR (1996) Identification of epoxyeicosatrienoic acids as endothelium-derived hyperpolarizing factors. Circ Res 78: 415-423.

53. Edwards G, Dora KA, Gardener MJ, Garland CJ, Weston AH (1998) K+ is an endothelium-derived hyperpolarizing factor in rat arteries. Nature 396: 269-272.

54. Edwards G, Thollon C, Gardener MJ, Félétou M, Vilaine J, et al. (2000) Role of gap junctions and EETs in endothelium-dependent hyperpolarization of porcine coronary artery. Br J Pharmacol 129: 1145-1154

55. Mather S, Dora KA, Sandow SL, Winter P, Garland CJ (2005) Rapid endothelial cell-selective loading of connexin 40 antibody blockes endothelium-derived hyperpolarizing factor dilation in rat small mesenteric arteries. Circ Res 97 : 399-407.

56. Lang NN, Luksha L, Newby DE, Kublickiene K (2007) Connexin 43 mediates endothelium-derived hyperpolarizing factor-induced vasodilatation in subcutaneous resistance arteries from healthy pregnant womem. Am J Physiol Heart Circ Physiol 292: 1026-32.

57. Guan BC, Si JQ, Jiang ZG (2007) Blockade of gap junction coupling by glycyrrhetinic acids in guinea pig cochlear artery: a whole-cell voltage- and current-clamp study. Br J Pharmacol 151: 1049-1060. 
Citation: Satoh H, Nishida S (2014) Cardio-Electopharmacology and Vasodilating Mechanisms of Quercetin. Med chem 4: 523-530. doi:10.4172/21610444.1000189

58. Murphy ME1, Brayden JE (1995) Apamin-sensitive K+ channels mediate an endothelium-dependent hyperpolarization in rabbit mesenteric arteries. $J$ Physiol 489: 723-734

59. García-Pascual A, Labadía A, Jimenez E, Costa G (1995) Endothelium- dependent relaxation to acetylcholine in bovine oviductal arteries: mediation by nitric oxide and changes in apamin-sensitive $\mathrm{K}+$ conductance. $\mathrm{Br} \mathrm{J}$ Pharmacol 115: 1221-1230. 